\title{
PRIVATE PROPERTY RIGHTS AND THE DECEASED
}

\section{Cole Green}

Loyola University New Orleans, New Orleans LA, USA

Alejandro Hernandez

Loyola University New Orleans, New Orleans LA, USA

\section{Walter E. Block}

Harold E. Wirth Eminent Scholar Endowed Chair and Professor of

Economics, Loyola University New Orleans, New Orleans LA, USA

(C) MESTE

JEL Category: D23, 030, P14

\begin{abstract}
While the libertarian theory of property rights has been thoroughly studied, there has been minimal research done in regard to a deceased person's ability to dictate the future of the property he owned in life. In this paper, we attempt to develop a theory of the property rights of deceased people consistent with libertarian principles. We analyze the legitimacy of contracts between two individuals after one individual dies, ownership of the cadaver, the deceased's right to decide which actions are permissible to perform on the said cadaver, and the status of the deceased property when a will both has and has not been written. While there has been no explicit commentary made regarding these topics, outside from the will, the authors extrapolated current libertarian theories on property rights and applied them accordingly. While the authors of the paper ultimately do not reach a consensus agreement on some of the issues discussed in the paper, this exploratory work on the property rights of the deceased is intended to open further discussion and research on the matter to further contribute to the formulation of a concise libertarian legal theory.
\end{abstract}

Keywords: private property; rights; deceased; cemetery; necrophilia.

\section{INTRODUCTION}

As Benjamin Franklin famously stated, "Nothing is certain but death and taxes". While there has been an enormous amount of literature written critiquing

Address of the corresponding author:

Cole Green

靠"cdgreen@my.loyno.edu the latter, there has not been much discussion about the former. ${ }^{1}$ Our discussion will not focus on the certainty of death but rather the interactions between the living and the deceased. There are vital questions regarding what should happen to a deceased person and all his belongings. Arguably, the most important question that must be addressed regarding the deceased is this: In a

1999; Ochoa \& Jones, 1996; Primoratz, 2001; Troyer, 2008

${ }^{1}$ Exceptions include the following: Alter, Kernochan, \& Darley, 2007; Benecke, 2008; Madoff, 2010; Naffine, 
libertarian ${ }^{2}$ society, should it be permitted for a living person to consummate with someone who is now deceased? Putting it more bluntly, should necrophilia be legal? Before discussing the legality of this despicable practice, the rights of the deceased must first be established. We will begin our exploration by tracing the ownership of the physical body after the moment of death. This will then lead to a discussion about the material property the deceased has left behind. After establishing the rights of the deceased and his property, we will get to the heart of our discussion, which is the legality of necrophilia. Before we begin our legal examination, we must say that some of the conclusions we reach will be uncomfortable, but that is the price that must be paid when searching for the truth.

In section 2 we define terms. Section 3 is given over to not very contentious claim that the dead body has no rights. The burden of section 4 is to ask who owns the body of the deceased person. In section 5 we discuss ownership of the property of the deceased Section 6 is our not to be missed conclusion.

\footnotetext{
2 Rothbard, 1972, 1983

${ }^{3}$ For a libertarian defense of homesteading, as the initial basis for property rights justification, see Block, 1990, 2002A, 2002B; Block and Edelstein, 2012; Block and Nelson, 2015; Block and Yeatts, 1999-2000; Block vs Epstein, 2005; Bylund, 2005, 2012; Grotius, 1625 Hoppe, 1993, 2011; Kinsella, 2003, 2006, 2009A, 2009B, 2009C; Locke, 1948; Paul, 1987; Pufendorf, 1673; Rothbard, 1969, 1973, 32; Rozeff, 2005; Watner, 1982
}

4 Nozick (1974) characterizes this process as any legitimate title transfer, such as barter, sale, lending, gifts, inheritance, gambling.

${ }^{5}$ There are some who oppose wills, inheritance, etc. For example, Buchanan (1983) urges that a $100 \%$ tax be placed on such transfers. See also on this: Batchelder, 2009-2010; Matthews, 2014; Prabhakar, 2008; White, 2008. Were this policy implemented, the present paper would be obviated. For an alternative view, however, see Block, 2011, 2012; Rothbard, 1973; Tabarrok, 2005; Tullock, 1971; States Rothbard (1973) on this matter: "Many people are willing to concede the justice and propriety of property rights and the free-market economy, to concede that the farmer should be able to charge whatever his wheat will bring from consumers or the worker to reap whatever others are willing to pay for his services. But they balk at one point: inheritance. If Willie Stargell is ten times as good and 'productive' a ball player as Joe Jack, they are willing to concede the

\section{DEFINE TERMS}

As per Lockean-inspired libertarianism, material objects are acquired as property through homesteading ${ }^{3}$ or voluntary transactions. ${ }^{4}$

If we are to adequately discuss death in a free society from this perspective, we must discuss the nature of a will. In this paper, we will consider a will to be any legal document that makes provision for the transfer of a dead individual's property to his heirs. We assume that the property is transferred at the moment of death so that the property has continuous ownership. ${ }^{5}$

\section{THE DEAD BODY HAS NO RIGHTS}

We are adopting a secular ontology of the body in this paper. ${ }^{6}$ While the living is endowed with natural rights ${ }^{7}$ due to their consciousness, the dead body is nothing more than a material object. We believe that this is a rational and scientific assumption because the dead body is nothing more than a cluster of inanimate materials. Any duty owed to property stems from the rights of the owner. For example, I cannot throw a brick through your windshield, as that would be an attack on your property. However, if I found a car

justice of Stargell's earning ten times the amount; but what, they ask, is the justification for someone whose only merit is being born a Rockefeller inheriting far more wealth than someone born a Rothbard? The libertarian answer is to concentrate not on the recipient, the child Rockefeller or the child Rothbard, but to concentrate on the giver, the man who bestows the inheritance. For if Smith and Jones and Stargell have the right to their labor and property and to exchange the titles to this property for the similar property of others, they also have the right to give their property to foowhomever they wish. And of course, most such gifts consist of the gifts of the property owners to their children-in short, inheritance. If Willie Stargell owns his labor and the money, he earns from it, then he has the right to give that money to the baby Stargell."

${ }^{6}$ We justify this on the grounds that we do not wish to quarrel with a straw man. Once religion enters the fray, the intellectual battle is over. Each denomination has its own rules on the use and disposal of dead bodies, and merely listing them would determine matters from that perspective.

7 The natural rights in a libertarian society are all negative: the right not to be murdered, raped, kidnapped, enslaved, stolen from, threatened; there are no positive rights in this philosophy, such as the right to food, clothing, shelter, or the right not to be discriminated against. 
abandoned in an unowned field, I could assault the windshield as I please. Since the dead body is a material item, any duty owed to it is strictly due to the rights of its owner. But this raises a question, who owns the dead body?

\section{OWNERSHIP OF THE PROPERTY OF THE DECEASED}

Before we establish the inheritance of the dead body, we will consider the transfer of the deceased's property. First, we consider the case with a will and then discuss what happens in its absence.

At the moment of death, any property for which a provision has been made in the will is transferred to the new owner. In a free society, any conditions placed on the transferred property are null and void. ${ }^{8}$ First, we must note that it is definitionally impossible to have a contract with a material object. For example, Jones cannot make a contract with a stick he found in his backyard. Consequently, no one can have a contract with a deceased person because that would be an agreement with a material object.

One interpretation of the foregoing is that while a will legally transfer property, any stipulations placed on the inheritance need not be met. To best explain this claim, imagine if Person A writes in his will that Person $B$ inherits his (A's) car only if he (B) paints it blue. Thus, the car will be transferred to B-so that he can paint it; but he need not paint it to keep it. Similarly, consider the case where Person A writes that his wife receives his body, and he wants her to bury it in their family plot. She inherits the body but may legally do whatever she pleases with it. While one hopes that people will follow the wishes of the dead for moral reasons, legally they have no such obligation.

For any property someone wishes to transfer with no conditions, a simple will should suffice. Similarly, a will works for someone who wishes to transfer property with conditions to someone that he trusts, for example to his loving wife or child.

However, what will Person A do if he does not trust Person $B$ to paint the car blue, or his wife to bury him as he wishes, safe from necrophiliacs?
At first glance, it appears that Person A can do nothing but a hope that Person B-(his wife) will honor his wishes. This seems like a devastating blow for libertarian property theory, but fear not, the free market once again rescues us with another option!

Person A will have access to a plethora of executor businesses, which will ensure that any conditions he $(A)$ has placed on the property (his dead body) are met. This will work as follows: Person A will hire an enforcer and he will discuss with him any conditions he wishes to place on the property in his will. Then, in that document, he will contract with the enforcer as the in effect intermediate inheritor of the property who will hold it until the final inheritor meets the condition necessary to inherit the property. For example, in his will, Person A will write that the lawyer who drew up the last will and testimony inherits the property and will transfer it to Person B only after he has painted the car blue, or in this case, she, his wife has buried his body safe from those who would abuse it. Thus, we see, once again, the will does not have an inanimate object, a stick, or a dead body as one of the signatories. The bequest either concerns the dying (but still alive) person and the beneficiary, or him and the enforcer.

That is one interpretation. Author three regards it as erroneous. In his view, enforcers are not necessary, because the contract's conditions on property transferred through will remain valid after death. Consequently, if, in his will, person A leaves a car to person $B$ on the condition that person $B$ paint the car blue, person B must paint the car blue to maintain ownership of the car. If person $\mathrm{C}$ was next in line to inherit the car and sees person $B$ cruising around in an unpainted car, person $\mathrm{C}$ could take person $B$ to court and sue him for the car for violating the conditions of inheritance.

Now, we must discuss what happens when there is no will, that is if the person dies intestate. Here is a typical explanation: ${ }^{9}$

"Every state has laws that direct what happens to property when someone dies without a valid will and the property was not left in some other way (such as in a living trust). Generally, only spouses,

\footnotetext{
${ }^{8}$ Deitman, 2002; Evers, 2014; Rothbard, 2007; Terrell, 2002
}

9 https://www.nolo.com/legal-encyclopedia/how-estatesettled-if-theres-32442.html 
registered domestic partners, and blood relatives inherit under intestate succession laws; unmarried partners, friends, and charities get nothing. If the deceased person was married, the surviving spouse usually gets the largest share. If there are no children, the surviving spouse often receives all the property. More distant relatives inherit only if there is no surviving spouse and if there are no children. In the rare event that no relatives can be found, the state takes the assets."

Author three believes this is highly compatible with libertarianism. In focusing on spouses and blood relatives, the law is attempting, reasonably too, a contrary to fact conditional: what would the deceased have wanted, while still alive. Since most people operate in such a manner, the law makes that the default position. If the property owner wanted something different, it would have been up to him to specify. The only divergence from typical law is about the government seizing these assets. There is already far too much of that already taking place. $^{10}$ Rather, we claim, the assets should be ruled abandoned, and given over to the first homesteader. 11

The first two authors do not agree that this is the proper default position. In a libertarian society, we cannot use the status quo as a justification for a law. As an example, it is a status quo to pay taxes, yet libertarian doctrine views taxation as theft. It is the opinion of the former authors that all libertarian laws must be justified through the NAP and property rights. The former authors believe that in

${ }^{10}$ On the case against asset forfeiture, see Baicker and Jacobson. 2007; Chi, 2002; Doyle, 2008; Moores, 2009; Naylor, 2000; Pimentel, 2012; Rothschild and Block, 2016A, 2016B; Rulli, 2001; Warchol and Johnson. 1996; Williams, Holcomb and Kovandzic, 2010, 2011. In the view of Rothbard (1982, 162): "Taxation is theft, purely and simply, even though it is theft on a grand and colossal scale which no acknowledged criminals could hope to match." Schumpeter $(1942,198)$ states: "The theory which construes taxes on the analogy of club dues or of the purchase of the services of, say, a doctor only proves how far removed this part of the social science is from scientific habits of mind." For further support for the notion that "taxation is theft," see Bagus, et. al., 2011; Block, 1989, 1993, forthcoming; Block and Barnett, 2003; Chodorov, 1962, 2017; DeJasay, 1997; Feser, 2000; Hoppe, 2008, 2011; Huemer, 2013, 2017; McGee, 2003; Portillo and Block, 2012; Rothbard, 1978, 1981, 1982; Schumpeter, 1942; Spenser, 1995; Spooner, 1870; Tame, 1989; Vance, 2006, 2007

11 According to author three, this refers to the physical goods, of course, not to the person's body. Author's one cases where there is no will, libertarian law needs a solution derived solely from the NAP and property rights. One possible solution is that property not transferred by a will is abandoned at the moment of death. This is consistent with the libertarian principle that property cannot be owned by a material object (i.e. a dead body). In this case, the property would be open for homesteading.

There is but one exception to this general rule: the friends of bum's case. If there are private charitable organizations that have been contributing to the upkeep of intestate folk, then it is they who would be the legitimate titleholders to their (physical) property.

\section{WHO OWNS THE BODY?}

At the instance of a person's death, the most immediate problem that arises is how to deal with the body. Since we have established that the body is nothing more than an immaterial object at this point the course of action depends if the recently deceased has left a will or not.

Let us start with the assumption that the deceased did have a will set up at the time of death. Thus, the deceased individual had ownership of his body until the moment of death. In this instance, just as with his material property ${ }^{12}$, ownership of the remains must be transferred to the new owner, determined through the will. In other words, the inheritor(s) of the deceased becomes the proprietor of the physical body. ${ }^{13}$

and two believe that the body is also open to homesteading, since it is reduced to a material good post mortem.

12 In regard to the functionality of wills regarding with deceased property, please refer to supra

13 Just as nature abhors a vacuum, the libertarian legal code abhors the state of non-ownership. Our motto is, if it moves, privatize it; if it does not move, privatize it. Since everything either moves or does not move, privatize everything. See on this: Anderson and Hill, 1996; Block, 2002, 2009, 2015, 2017A, 2017B; Block and Nelson, 2015; Butler, 1988; Carnis, 2003; Ebeling, 2013; Hanke, 1987A, 1987B; Hannesson, 2004, 2006; Hoppe, 2011; Karpoff, 2001; Megginson, 2001; Moore, 1987; Moore and Butler, 1987; Motichek, Block and Johnson, 2008; Nelson and Block, 2018; Ohashi, 1980; Ohashi, Roth, Spindler, McMillan and Norrie, 1980; Pirie, 1986; Rothbard, 2018; Savas, 1987; Walker, 1988; White, 1978 
Since this new person is now the proprietor of the physical body, he has the legal jurisdiction as to its status. For example, let us say that Person $A$ has recently passed away. In his will, he left person $B$ as the sole proprietor of his possessions. Also assume that in our free society, the social norm was that recently deceased bodies must be burned in a giant fire pyre within 48 hours. Would $B$ be obligated to burn the body of person $A$ within the allotted time frame? The answer to this question should come as no surprise to any true follower of libertarianism. It all depends on whatever action person $B$ has a higher preference for. He could follow the social norm and burn the body, or he could do whatever he sees fit with it, such as donating it to science, trading it, displaying it, etc. The important thing is that it is unimportant what $B$ ends up deciding to do. Since it is now his property, he can do whatever he sees fit with it just like he could decide what to do with the shirt in his closet. It is important to note that this is only analyzing their choice through legal analysis. While we are claiming $B$ can legally do whatever he wants with the body, we are taking no moral stance on his decision. He may still face social repercussions for disregarding the norm, but that is outside the scope of the present paper. Of course, A may well have stipulated that $B$ is to cremate his body or place it in a cemetery. For an elaboration on this case, please refer to section IV

Now consider the case in which $A$ dies on someone's property, $\mathrm{C}$, who is not the heir expressed in the will. Must he give up the body? At present, as a matter of fact, there are of course laws concerning this sort of thing, and they will be followed. But, we ask, what should the law provide under these circumstances under the private property, free society. Presumably, libertarian laws would eventually cover this situation. Here, the opinions of the authors diverge. According to author three, at present, we can only rely on the doctrine of implicit contracts (Kern, 2019). If you go to a restaurant, order and drink a cup of coffee, and they present you with a bill for $\$ 1$ million, you are not at all obligated to pay anything like that amount. There is an implicit contract in operation such that they will charge a "reasonable" price. If they wish to engage in astronomical pricing, they must obtain your explicit agreement.

Authors one and two disagree with the previous analysis. We hold that two conditions are necessary for a contract in libertarian society: First, there must be a meeting of the minds between the two parties, i.e. both parties must comprehend the terms of the contract and agree to them in an appropriate state of mind. Second, the terms of the contract must be laid out in a written (or some other form which can be revisited at a later date) document signed (or the equivalent act for the form used) by both parties. This requirement] We believe that in a libertarian society, implicit contracts have no legal authority.

In general, we reject the ability of two parties to form an implicit contract and only accept the validity of explicit contracts. This relies on the assumption that the consumer thinks he will be charged a reasonable price for the cup of coffee. This reasonable price, in turn, is based on the production costs of the cup of coffee. In our view, this defense is highly problematic. Only explicit contracts count. It is essential that an explicit contract be signed before any transaction is considered valid in the libertarian society. For example, let us assume that no explicit contract was signed before the barista brings the customer the coffee, whereupon the customer drinks the coffee and is then presented with a $\$ 1$ million bill. If the customer believes this price to be absurd, he has no obligation to pay for the coffee because no explicit contract was signed. He may simply walk out of the store without penalty. In practice, in cases where no explicit contract is signed, the barista will present a reasonable bill which the customer will pay so that he may continue to return to the store; or he may do so out of good manners. However, since we cannot rely on all patrons and customers to act reasonably if two parties wish to avoid the absurd $\$ 1$ million coffee bills and dineand-dash customers, they must sign an explicit contract before the exchange occurs. Only in this way can both parties be sure that they will receive a reasonable bill and make reasonable payment.

The erroneous justification of an implicit reasonable price relies on the aggregate marginal utility cost for a cup of coffee. To define what a reasonable price is, one must look through all of the industry's coffee cup transactions and create a scale to determine what the average costs were. Aside from this tedious task, it is also incompatible with the Austrian view of the source of pricing (Mises, 2006). For the seller, the materials needed to produce the cup of coffee may very well have 
been cheap, but he could have valued their labor at only slightly less than $\$ 1$ million. The seller would only sell the cup of coffee at a minimum of $\$ 1$ million because anything lower than that, he would gain more value from keeping it than selling it. According to the implicit contract argument, this would nullify the value that the coffee seller and also is incompatible with the libertarian principle of the free association since the seller is allowed to set a price on his property. Aside from this, if the coffee owner did value the cup at $\$ 1$ million, then there would not be an instance where the buyer would not know the cost of the coffee because it is too big of a risk for the seller to not disclose it in some way (on the menu, verbally, charge before providing the product, etc..) to his potential buyer. In addition to these notifications, the explicit contract signed by both parties would clearly state the terms of the transaction. If the buyer did not wish to pay, which price the seller presented in the explicit contract, and still bought the beverage thinking he was merely kidding, this would be pure negligence on the part of the buyer. He should still be required to pay the full $\$ 1$ million price to the seller because all explicit contracts are binding (assuming both parties are in a proper state of mind, i.e. sober, mentally fit, etc.) The seller should not be punished for the negligence of the buyer.

In like manner, if A dies on C's property unless there is an explicit agreement to the contrary. We still believe that this claim is not needed to conform to libertarian law. It's not a disagreement but rather we see this has no fit in our paper as it is a moral claim of doing the right thing instead of if they are required to.

Must we acquiesce to the radical claim that a dead person's body, without a will, is immediately open to acquisition through homesteading? That is, horrors if a necrophiliac were the first person to happen upon this piece of inanimate flesh, could he properly wreak his evil will upon the remains? We need not make any such thing concession. We

14 This includes roads, streets and highways (Block, 2009) as well as bodies of water such as lakes, rivers, oceans (Block, and Nelson. 2015.)

15 The first two mentioned authors maintain the invalidity of implicit contracts in all contexts, this one included. For their reasoning, see fn. 11, supra. need not assent to any such scenario. Remember, in a fully free society, all surfaces of Earth, without exception, will be privately owned. ${ }^{14}$ There would be implicit contracts in all of these cases, presumably, to prohibit necrophilia. ${ }^{15}$

The only exception would be land owned by the "Necrophilia Society." Under the libertarian legal code, they would be allowed to engage in these abominable practices, since they do not constitute an explicit rights violation when performed upon the bodies of people who in effect bequeath themselves to preposterous such goings-on. Normal people will avoid such territory as if there were a plague infecting them there.

Lastly, like any other property, the body can be abandoned ${ }^{16}$. If so, the above considerations would apply.

Now consider a normal burial. As long as the grave plot is maintained as private property, the body cannot be disturbed without the owner's permission just as a car left in a garage is protected by property rights. The body interred in the grave may not be pillaged by gravediggers. The owner could revoke the dead body as his property or could leave the body for so long that it is considered abandoned. In this case, anyone who stumbles across the abandoned grave can homestead the body. What if a cemetery is abandoned by its owner; would the bodies interred in the graves become fair game for grave robbers? Not a bit of it. In the free society, this possibility would be anticipated, and reasonable accommodations made to obviate any such occurrence. Presumably, insurance firms would prevent it. ${ }^{17}$

\section{CONCLUSION}

We have attempted in this paper to confront a complicated issue, rarely discussed in the literature, at least not from a libertarian private property rights perspective. No doubt we have erred in several areas. But, better to start

16 See on this Block, 2004, 2015; Block and Nelson, 2015; Kinsella, 2003, 2009A, 2009B, 2009C, 2011; Long, 1993; Wisniewski, 2010.

17 For the role insurance companies would play in obviating all sorts of unlikely occurrences, for challenges to the free society refuted see Block, 1998; Hoppe, 1999, 2006; Murphy, 2002; Semmens, 1995 
somewhere, than not at all in taking on difficult challenges. We hope that this paper will lead to a fuller discussion and we will thus have started down the path of arriving by that proverbial onemillionth of an inch closer to the Truth on this matter with a capital $\mathrm{T}$.

\section{WORKS CITED}

Alter, A. L., Kernochan, J., \& Darley, J. (2007). Morality Influences How People Apply the Ignorance of the Law Defense. Law \& Society Review, 41(4), 819-864. Retrieved from www.jstor.org/stable/4623416

Anderson, T. L., \& Hill, P. J. editors. (1996). The privatization process: a worldwide perspective. Lanham, Md.: Rowman \& Littlefield Publishers.

Baicker, K., \& Jacobson, M. (2007). Finders Keepers: Forfeiture Laws, Policing Incentives, and Local Budgets. Journal of Public Economics, Elsevier B.V., pp. 2113-2136; http://users.nber.org/ jacobson/BaickerJacobson2007.pdf

Batchelder, L. L. (2009-2010). What Should Society Expect from Heirs - The Case for a Comprehensive $\begin{array}{lllllll}\text { Inheritance } & \text { Tax. } & 63 & \text { Tax } & \text { L. } & \text { Rev. } & 1\end{array}$ http://heinonline.org/HOL/LandingPage?handle=hein.journals/taxlr63\&div=5\&id=\&page=

Bagus, P., Block, W. E., Eabrasu, M., Howden, D., \& Rostan, J. (2011). The ethics of tax evasion. Business and Society Review, 116(3), 375-402; http://www.walterblock.com/wpcontent/uploads/V.355_The-ethics-of-tax-evasion.pdf

Buchanan, J. (1983). Rent-Seeking, Non-compensated Transfers, and Laws of Succession. Journal of Law and Economics, 26(1), 71-85

Benecke, M. (2008). "Clandestine Necrophilia - Probably Legal, Still A Problem." Anil Aggrawal's Internet Journal of Forensic Medicine \& Toxicology, 9(2), 5. Retrieved from https://search.ebscohost.com/login.aspx?direct=true\&db=a9h\&AN=34078235\&site=eds live\&scope $=$ site

Block, W. E. (1989). The Justification of Taxation in the Public Finance Literature: An Unorthodox View. Journal of Public Finance and Public Choice, (3), 141-158

Block, W. E. (1990). Earning Happiness Through Homesteading Unowned Land: a comment on 'Buying Misery with Federal Land' by Richard Stroup. Journal of Social Political and Economic Studies, 15(2), 237-253.

Block, W. E. (1993). Canadian Public Finance Texts Cannot Justify Government Taxation: A Critique of Auld \& Miller; Musgrave, Musgrave \& Bird; McCready; and Wolf. Canadian Public Administration, 36(2), 225-262;

Block, W. E. (1998). Private Roads, Competition, Automobile Insurance, and Price Controls. Competitiveness Review, 8(1), 55-64

Block, W. E., \& Yeatts, G. 1999-2000. The Economics and Ethics of Land Reform: A Critique of the Pontifical Council for Justice and Peace's 'Toward a Better Distribution of Land: The Challenge of Agrarian Reform', Journal of Natural Resources and Environmental Law, 15(1), 37-69

Block, W. E. (2002A). Homesteading City Streets; An Exercise in Managerial Theory. Planning and Markets, 5(1), 18-23; September, http://www-pam.usc.edu/volume5/v5i1a2s1.html; http://wwwpam.usc.edu/

Block, W. E. (2002B). On Reparations to Blacks for Slavery. Human Rights Review, 3(4), JulySeptember, pp. 53-73 
Block, W. E. (2002). Radical Privatization and other Libertarian Conundrums. The International Journal of Politics and Ethics, 2(2), 165-175; https://www.walterblock.com/publications/radical_privatization.pdf

Block, W. E., \& Barnett II, V. (2003, July 12). Voluntary Taxes: Abusive Language and Politicians. http://archive.lewrockwell.com/block/block28.html

Block, W. E. (2004). Libertarianism, Positive Obligations, and Property Abandonment: Children's Rights. International Journal of Social Economics, 3(3), 275-286

Block, W. E. v. Epstein, R. (2005). Debate on Eminent Domain. NYU Journal of Law \& Liberty, 1(3), 1144-1169

Block, W. E. (2009). The Privatization of Roads and Highways: Human and Economic Factors. Auburn, AL: The Mises Institute

Block, W. E. (2011). Toward a libertarian theory of charitable donations. Economics, Management, and Financial Markets, 6(4), 9-28; http://www.walterblock.com/wp-content/uploads/V.378_Towarda-libertarian-theory-of-charitable-donations.pdf

Block, W. E. (2012). James Buchanan on Inheritance: a Critique. Journal of Entrepreneurship \& Public Policy, 1(2), 159 - $165 . \quad$ http://www.emeraldinsight.com/journals.htm?issn=20452101\&show=latest;

http://www.emeraldinsight.com/fwd.htm?id=aob\&ini=aob\&doi=10.1108/20452101211261435; https://www.deepdyve.com/lp/emerald-publishing/james-buchanan-on-inheritance-a-critiqueE3KqWgbcZ4

Block, W. E., \& Edelstein, M. R. (2012, Spring). Popsicle sticks and homesteading land for nature preserves. Romanian Economic and Business Review. 7(1), 7-13. http://www.rebe.rau.ro/REBE\%207\%201.pdf

Block, W. E. (2015, Spring). Expiration of private property rights. The Journal of Philosophical Economics, 8(2), http://www.jpe.ro/?id=revista\&p=410; http://www.jpe.ro/pdf.php?id=7114

Block, W. E., \& Nelson, P. L. (2015). Water Capitalism: The Case for Privatizing Oceans, Rivers, Lakes, and Aquifers. New York City, N.Y.: Lexington Books; Rowman and Littlefield; https://rowman.com/ISBN/9781498518802/Water-Capitalism-The-Case-for-PrivatizingOceans-Rivers-Lakes-and-Aquifers.

Block, W. E. (2017A, Summer). Radical Privatization: Oceans, Roads, Heavenly Bodies. Romanian Economic and Business Review, (12), 41-56; http://www.rebe.rau.ro/RePEc/rau/journl/SU17/REBE-SU17-A4.pdf; https://econpapers.repec.org/article/raujournl/v_3a12_3ay_3a2017_3ai_3a2_3ap_3a41-56.htm

Block, W. E. (2017B). Privatizing government, in the interim. The Journal of Private Enterprise, 32(3), 33-45;

http://journal.apee.org/index.php?title=2017_Journal_of_Private_Enterprise_vol_32_no_3_Fall _parte4.pdf

Block, W. E. (Forthcoming). Murray Rothbard, Anarchist. Anarchy Handbook, Chad Van Schoelandt, editor

Butler, E. ed. (1988). The Mechanics of Privatization. London: Adam Smith Institute

Bylund, Per. (2005, June). Man and Matter: A Philosophical Inquiry into the Justification of Ownership in Land from the Basis of Self-Ownership. Master thesis, Lund University, http://www.uppsatser.se/uppsats/a7eb17de8f/;

http://perbylund.com/academics_polsci_msc.pdf; http://www.essays.se/essay/a7eb17de8f/; http://www.lunduniversity.lu.se/o.o.i.s?id=24965\&postid=1330482 
Bylund, P. (2012). Man and matter: how the former gains ownership of the latter. Libertarian Papers, 4(1). http://libertarianpapers.org/articles/2012/lp-4-1-5.pdf

Carnis, L. (2003). The Case for Road Privatization: A Defense by Restitution. Journal des Economistes et des Etudes Humaines, 13(1) 95-116

Chi, KAY. (2002, Oct). Follow the Money: Getting to the Root of the Problem with Civil Asset Forfeiture in California. California Law Review, 90(5), 1635-1673

Chodorov, F. (1947). Taxation Is Robbery. Human Events Pamphlets, 15, 1-24. Retrieved from https://archive.org/details/ChodorovFrankTaxationlsRobberyPDF

Chodorov, F. (2017, Nov 8). Taxation Is Robbery. https://mises.org/library/taxation-robbery

De Jasay, A. (1997). Against Politics: On Government, Anarchy, and Order. London: Routledge.

Dieteman, D. F. (2002, July 30). Courts, Contracts, and the EEOC. https://mises.org/library/courtscontracts-and-eeoc

Doyle, C. (2008). Crime and Forfeiture. Nova Science Publishers. pp. 1-89. http://digital.library.unt.edu/ark:/67531/metadc282308/m1/1/high_res_d/97139_2013May13.pdf

Ebeling, R. (2013). Why Not Privatize Foreign Policy? Retrieved from: https://epictimes.com/article/127064/why-not-privatize-foreign-policy

Evers, W. M. (2014, July 30). Toward a Reformulation of the Law of Contracts. Retrieved from: https://mises.org/library/toward-reformulation-law-contracts

Feser, E. (2000, Fall). Taxation, Forced Labor, and Theft. The Independent Review, pp. 219-235

Grotius, H. (1625). Law of War and Peace (De Jure Belli ac Pacis), 3 volumes; translated by A.C. Campbell, London, 1814

Hanke, S. H., ed., (1987A). Privatization and Development. San Francisco: Institute for Contemporary Studies

Hanke, S. H. (1987B). Privatization. In J. Eatwell, M. Milgate \& P. Newman, eds., The New Palgrave: A Dictionary of Economics, v. 3. London: The Macmillan Press, Ltd.: 976-77.

Hannesson, R. (2004). The Privatization of the Oceans, in D.R. Leal (Ed.): Evolving Property Rights in Marine Fisheries, Lanham, Md.: Rowman and Littlefield, pp. 25-48.

Hannesson, R. (2006). The Privatization of the Oceans. Cambridge, MA: MIT Press.

Hoppe, H. H. (1993). The Economics and Ethics of Private Property: Studies in Political Economy and Philosophy. Boston: Kluwer

Hoppe, H. H. (1999, Winter). The private production of defense." Journal of Libertarian Studies 14, no. 1 (Winter): 27-52; http://mises.org/journals/jls/14_1/14_1_2.pdf

Hoppe, H. H. (2006, Mar 7). Uncertainty and Its Exigencies: The Critical Role of Insurance in the Free Market. Retrieved from: http://www.mises.org/story/2021

Hoppe, H. H. (2008, June 23). Reflections on the Origin and the Stability of the State. https://www.lewrockwell.com/hoppe/hoppe18.html

Hoppe, H. H. (2011). Of Private, Common, and Public Property and the Rationale for Total Privatization. Libertarian Papers 3(1), 1-13. https://libertarianpapers.org/2011/1-hoppe-private-common-andpublic-property/

Hoppe, H. H. (2011, Apr 10). State or Private Law Society. https://www.lewrockwell.com/hoppe/hoppe26.1.html 
Huemer, M. (2013).The Problem of Political Authority. New York: Palgrave Macmillan

Huemer, M. (2017A, Mar 16). Is Taxation Theft?. Retrieved from: https://www.libertarianism.org/columns/is-taxation-theft

Huemer, M. (2017B). Is Wealth Redistribution a Rights Violation?. The Routledge Handbook of Libertarianism, ed. J. Brennan, D. Schmidtz, \& B.v.d. Vossen, Routledge

Karpoff, J. M. (2001). Public versus Private Initiative in Arctic Exploration: The Effects of Incentives and Organizational Structure. The Journal of Political Economy, 109(1), 38-78.

Kern, A. (2019, Oct 16). Why the State Can't Claim Our Implied Consent. https://mises.org/wire/whystate-cant-claim-our-implied-consent?utm_source=Mises+Institute+Subscriptions\&utm_ campaign=5d572b24a1-EMAIL_CAMPAIGN_9_21_2018_9_59_COPY_01\&utm_medium= email\&utm_term=0_8b52b2e1c0-5d572b24a1-227976965

Kinsella, S. N. (2003). A libertarian theory of contract: title transfer, binding promises, and inalienability. Journal of Libertarian Studies, 17(2), 11-37; http://www.mises.org/journals/jls/17_2/17_2_2.pdf

Kinsella, S. N. (2006, Sep 7). How we come to own ourse/ves. https://www.mises.org/story/2291; https://mises.org/library/how-we-come-own-ourselves

Kinsella, S. N. (2009A, Aug 21). What Libertarianism Is. https://mises.org/library/what-libertarianism

Kinsella, S. N. (2009B). What Libertarianism Is, in J. G. Huelsmann \& S. Kinsella, eds., Property, Freedom, and Society: Essays in Honor of Hans-Hermann Hoppe (Auburn AL: Mises Institute)

Kinsella, S. N. (2009C, May 22). Homesteading, Abandonment, and Unowned Land in the Civil Law. http://blog.mises.org/10004/homesteading-abandonment-and-unowned-land-in-the-civil-law/

Kinsella, S. N. (2011, Oct 4). The relation between the non-aggression principle and property rights: a response to Division by Zero. https://blog.mises.org/18608/the-relation-between-the-nonaggression-principle-and-property-rights-a-response-to-division-by-zer0/

Locke, J. (1948). An Essay Concerning the True Origin, Extent, and End of Civil Government, in E. Barker, ed., Social Contract, New York: Oxford University Press, pp. 17-19.

Long, R. T. (1993, Winter). Abortion, Abandonment, and Positive Rights: The Limits of Compulsory Altruism. Social Philosophy and Policy, 10(1), 166-191. http://praxeology.net/RTL-Abortion.htm

Madoff, R. (2010). Controlling the body. In Immortality and the Law: The Rising Power of the American Dead (pp. 12-56). New Haven; London: Yale University Press. Retrieved from www.jstor.org/stable/j.ctt1nq16h.5

Manderson D. (Ed.), Courting Death: The Law of Mortality (pp. 95-110). London; Sterling, Virginia: Pluto Press. doi:10.2307/j.ctt18fs9gk.9

Matthews, D. (2014, July 24). Why Isn't Inheritance Tax 100\%? Forbes; http://www.forbes.com/sites/danmatthews/2014/07/24/why-isnt-inheritance-tax-100-percent/\#43124e9d6408

McGee, R. W. (2003). The philosophy of taxation and public finance. Kluwer

McKearn, S. (2008). Dead Sexy: An Essay on the Ethics of Necrophilia. Anil Aggrawal's Internet Journal of Forensic Medicine \& Toxicology, 9(2), 4. Retrieved from https://search.ebscohost.com/login. aspx?direct=true \&db=a9h\&AN=34078234\&site=edslive\&scope=site

Megginson, W., \& Netter, J. (2001). From State to Market: A Survey of Empirical Studies on Privatization. Journal of Economic Literature, 39(2), 321-89. 
Mises, L. V. (2006). The Source of Pries. Accessed March 5, 2020. https://mises.org/library/sourceprices.

Moore, S. (1987). Privatizing the U.S. Postal Service, in S. Moore \& S. Butler, eds., Privatization, Washington: Heritage Foundation.

Moore, S., \& Butler, S. eds., (1987). Privatization. Washington: Heritage Foundation.

Moores, E. (2009). Reforming the Civil Asset Forfeiture Reform Act. Arizona Law Review, 51, pp. 777803; http://www.arizonalawreview.org/pdf/51-3/51 arizlrev777.pdf

Motichek, A., Block W. E., \& Johnson, J. (2008, June). Forget Ocean Front Property, We Want Ocean Real Estate! Ethics, Place, and Environment, 11(2), 147-155

Murphy, R. P. (2002). Chaos Theory: Two Essays on Market Anarchy. New York: RJ Communications LLC. http://mises.org/books/chaostheory.pdf

Naffine, N. (1999). 'But a Lump of Earth'?: The Legal Status of the Corpse.

Naylor, R.T. (2000). "Wash-out: A Critique of Follow-The-Money Methods in Crime Control Policy." Crime, Law \& Social Change, Netherlands: Kluwer Academic Publishers, 1-57.

Nelson, P. L., \& Block W. E. (2018). Space capitalism: the case for privatizing space travel and colonization. Palgrave Macmillan

Nozick, R. (1974). Anarchy, State, and Utopia. New York: Basic Books

Ochoa, T. T., \& Jones, C. N. (1996). Defiling the Dead: Necrophilia and the Law. Whittier Law Review, (3), 539. Retrieved from https://search-ebscohost-com.ezproxy.loyno.edu/login.aspx? direct=true\&db=edshol\&AN=edshol.hein.journals. whitlr18.35\&site=eds-live\&scope=site

Ohashi, T.M. (1980). Privatization, theory and practice: distributing shares in private and public enterprise. The Fraser Institute, Vancouver, B.C.

Paul, E. F. (1987). Property Rights and Eminent Domain. Livingston, New Jersey: Transaction Publishers

Prabhakar, R., Rowlingson, K., \& White, S. (2008). How to Defend Inheritance Tax. Fabian ideas, 623. Fabian Society.

Pimentel, D. (2012). Forfeitures Revisited: Bringing Principle to Practice in Federal Court. Nevada Law Journal, 13(1), 3-59

Pirie, M. (1986). Privatization in Theory and Practice. London: Adam Smith Institute

Portillo, J., \& Block, W. E. (2012). Negative Effects of U.S. Taxation. Studies in Economics and Finance, 29(2)

Primoratz, I. (2001). Sexual Morality: Is Consent Enough?, Ethical Theory and Moral Practice, 4(3), 201218. Retrieved from www.jstor.org/stable/27504193

Pufendorf, S. (1673). Natural law and the law of nations (De officio hominis et civis prout ipsi praescribuntur lege naturali) De officio hominis et civis juxta legem naturalem libri duo. 2 vols., Volume 1: Text, Buffalo, NJ, Hein; reprint of New York, Oxford U. Pr., 1927a.

Rothbard, M. N. (1969, June 15). Confiscation and the Homestead Principle. The Libertarian Forum, 1(6). https://www.panarchy.org/rothbard/confiscation.html

Rothbard, M. N. (1973). For a New Liberty, Macmillan, New York; http://www.mises.org/rothbard/newliberty.asp

Rothbard, M. N. (1981). The Myth of Neutral Taxation. The Cato Journal, 1(2), 519-564. 
Rothbard, M. N. 1998 [1982]. The Ethics of Liberty. New York: New York University Press. http://www.mises.org/rothbard/ethics/ethics.asp

Rothbard, M. N. (2007, June 22). Property Rights and the Theory of Contracts. https://mises.org/library/property-rights-and-theory-contracts

Rothbard, M. N. (2018, Feb 18). How to Desocialize. https://mises.org/wire/how-desocialize

Rothschild, D. Y., \& Block, W. E. (2016A). Don't Steal; The Government Hates Competition: The Problem with Civil Asset Forfeiture. The Journal of Private Enterprise, 31(1), 45-56; http://journal.apee.org/index.php/2016_Journal_of_Private_Enterprise_vol_31_no_1_parte4.p df

Rothschild, D. Y., \& Block, W. E. (2016B). It Is Not Armed Robbery When Government Takes People's Stuff, It Is Civil Asset Forfeiture. Journal of Social and Administrative Sciences, 3(3), 219-230. www.kspjournals.org; $\quad$ http://www.kspjournals.org/index.php/JSAS/article/view/912; http://www.kspjournals.org/index.php/JSAS/article/view/912/1029

Rozeff, M. S. (2005, Sep 01). Original Appropriation and Its Critics. http://www.lewrockwell.com/rozeff/rozeff18.html

Rulli, L. S. (2001). The Long-Term Impact of CAFRA: Expanding Access to Counsel and Encouraging Greater Use of Criminal Forfeiture. Federal Sentencing Reporter, 14(2), Forfeiture: Recent Reform and Future Outlook, University of California Press: Vera Institute of Justice, pp. 87-97.

Savas, E. S. (1987). Privatization. Chatham, N.J.: Chatham House Publishers.

Schumpeter, J. A. (1942). Capitalism, Socialism and Democracy. New York: Harper Press.

Semmens, J. (1995). Privatizing Vehicle Registrations, Driver's Licenses and Auto Insurance. Transportation Quarterly, 49(4), 125-135

Spencer, H. (1995). Social Statics. New York: Robert Schalkenbach Foundation.

Spooner, L. 1870 [1973]. No Treason No. VI: The Constitution of No Authority at 15, in No Treason: The Constitution of No Authority and A Letter to Thomas F. Bayard. Ralph Myles Publisher

Tabarrok, A. (2005, July 20). Death Taxes: Theory, History, and Ethics. https://mises.org/system/tdf/deathtax_4.pdf?file=1\&type=document

Tame, C. R. (1989). Taxation Is Theft. Libertarian Alliance Political Note No. 44

Terrell, T. D. (2002, Jan 18). Court Shreds Contracts. https://mises.org/library/court-shreds-contracts

Troyer, J. (2008). "Abuse of a corpse: A brief history and re-theorization of necrophilia laws in the USA." Mortality, 13(2), 132-152. https://doi-org.ezproxy.loyno.edu/10.1080/13576270801954518

Tullock, G. (1971). Inheritance Justified. The Journal of Law \& Economics, 14(2), 465-474; http://www.jstor.org/stable/724956?seq=1\#page_scan_tab_contents

Vance, L. M. (2006, Oct 09). The Fraudulent Tax. http://www.mises.org/story/2327

Vance, L. M. (2007, Apr 16). Real Tax Reform. http://www.mises.org/story/2552

Walker, M A. (1988). Privatization: Tactics and Techniques. The Fraser Institute, Vancouver, B.C., Canada

Warchol, G. L., \& Johnson, B. R. (1996). Guilty Property: A Quantitative Analysis of Civil Asset Forfeiture. American Journal of Criminal Justice 21(1), 61-81.

Watner, C. (1982). The Proprietary Theory of Justice in the Libertarian Tradition. Journal of Libertarian Studies, 6(3-4), 289-316. http://mises.org/journals/jls/6_3/6_3_6.pdf 
Wisniewski, J. B. (2010a). A Critique of Block on Abortion and Child Abandonment. Libertarian Papers 2(16). http://libertarianpapers.org/2010/16-wisniewski-block-on-abortion/

White, L. H. (1978). Privatization of municipally-provided services. The Journal of Libertarian Studies, 2(2), 187-197

White, S. (2008). What (if Anything) is Wrong with Inheritance Tax? The Political Quarterly, 79(2), 162171, http://onlinelibrary.wiley.com/doi/10.1111/j.1467-923X.2008.00921.x/full

Williams, M. R., Holcomb, J. E. \& Kovandzic, T. V. (2010). Policing for Profit: The Abuse of Civil Asset Forfeiture. Institute for Justice, 6-120. http://www.ij.org/images/pdf_folder/other_pubs/assetforfeituretoemail.pdf

Williams, M. R., Holcomb, J. E. \& Kovandzic, T. V. (2011). Civil Asset Forfeiture, Equitable Sharing, and Policing for Profit in the United States. Journal of Criminal Justice, pp. 273-285. http://walkerfoundation.org/files/walker/2011/afjournalofcriminaljustice.pdf

Received for publication: $\quad$ 09.06.2020

Revision received: $\quad 28.11 .2020$

Accepted for publication: $\quad 30.12 .2020$

\section{How to cite this article?}

Style - APA Sixth Edition:

Green, C., Hernandez, A., \& Block, W. E. (2021, January 15). Private property rights and the deceased.

(Z. Cekerevac, Ed.) MEST Journal, 9(1), 15-27. doi:10.12709/mest.09.09.01.03

Style - Chicago Sixteenth Edition:

Green, Cole, Alejandro Hernandez, and Walter E. Block. 2021. "Private property rights and the deceased." Edited by Zoran Cekerevac. MEST Journal (MESTE) 9 (1): 15-27. doi:10.12709/mest.09.09.01.03.

Style - GOST Name Sort:

Green Cole, Hernandez Alejandro and Block Walter E. Private property rights and the deceased [Journal] // MEST Journal / ed. Cekerevac Zoran. - Belgrade - Toronto : MESTE, January 15, 2021. 1 : Vol. 9. - pp. 15-27.

Style - Harvard Anglia:

Green, C., Hernandez, A. \& Block, W. E., 2021. Private property rights and the deceased. MEST Journal, 15 January, 9(1), pp. 15-27.

Style - ISO 690 Numerical Reference:

Private property rights and the deceased. Green, Cole, Hernandez, Alejandro and Block, Walter E. [ed.] Zoran Cekerevac. 1, Belgrade - Toronto : MESTE, January 15, 2021, MEST Journal, Vol. 9, pp. 15-27. 